JKEP

Vol 6, No 2 (2021)

ISSN: 2338-9095 (Print)

ISSN: 2338-9109 (online)

\title{
Gambaran Ketergantungan Gadget Pada Anak Usia Sekolah
}

\author{
Nurfitri Rahmawati, Herlina, Yesi Hasneli N \\ Fakultas Keperawatan Universitas Riau \\ Email: nurfitri.rahmawati08@gmail.com
}

Artikel history

Dikirim, Sept 09th, 2020

Ditinjau, Oct 31th, 2021

Diterima, Nop 19th, 2021

\begin{abstract}
Excessive usage of gadgets can lead to addiction for school-age children, which has some impacts on the child's physical and psychosocial development. This study aims to describe the dependence of gadgets on school-age children. This study used a descriptive design. The sample of this study was 30 respondents who were taken by non-probability sampling technique, namely purposive sampling. The measuring instrument of this study was the Smartphone Addiction Scale Short Version (SAS-SAV) questionnaire. Data analysis used simple descriptive. Most of respondents were 11 years old (66.7\%), boy (70\%), first-born (36.7\%), fifth grade (70.0\%), application used was games (83.3\%), usage time of gadget was 1-2 hours (36.7\%) and the owner of gadget for respondents was their parents (63.3\%). The results of this study indicate that more than half of the respondents who are addicted to gadgets are 53.3\%. This study recommends to community, especially families, to be able to monitor their children in the usage of gadget and can prevent gadget addiction in school-age children.
\end{abstract}

Keywords: dependency; gadget; school-age children

\begin{abstract}
ABSTRAK
Penggunaan gadget secara berlebihan pada anak usia sekolah dapat menyebabkan terjadinya kecanduan yang menimbulkan dampak bagi perkembangan fisik maupun psikososial anak. Penelitian ini bertujuan untuk melihat gambaran ketergantungan gadget pada anak usia sekolah. Penelitian ini menggunakan desain deskriptif. Sampel penelitian ini sebanyak 30 responden dengan teknik non probability sampling yang digunakan yaitu purposive sampling. Alat ukur penelitian ini adalah kuesioner Smartphone Addiction Scale Short Version (SASSV). Analisa data yang digunakan ialah deskriptif. Paling banyak responden berusia 11 tahun $(66,7 \%)$, berjenis kelamin laki-laki $(70 \%)$, lebih banyak anak pertama $(36,7 \%)$, kelas 5 $(70,0 \%)$, aplikasi yang digunakan adalah games $(83,3 \%)$, waktu penggunaan gadget adalah 12 jam $(36,7 \%)$ dan kepemilikan gadget pada responden adalah milik orang tua $(63,3 \%)$. Hasil penelitian ini menunjukkan bahwa lebih dari setengah responden yang mengalami kecanduan gadget yaitu 53,3\%. Penelitian ini merekomendasikan kepada masyarakat khususnya keluarga untuk dapat mengawasi anaknya dalam penggunaan gadget dan dapat mencegah terjadinya kecanduan pada anak usia sekolah.
\end{abstract}

Kata kunci: anak usia sekolah; gadget; ketergantungan 


\section{PENDAHULUAN}

Anak usia sekolah berusia antara 7 sampai 12 tahun (Kesehatan, 2011). Masa ini ditandai dengan aktifitas motorik, bahasa, kognitif, dan sosial emosi (Latifa, 2017). Periode ini anak mulai memperoleh dasar pengetahuan atau kemampuan kognitif untuk mengenal dunia baru, bertanggung jawab atas perilakunya sendiri dengan lingkungan sekitarnya, berinteraksi dengan teman sebaya dan mendapatkan pujian atau penguatan (reinforcement) dalam memperoleh rasa pencapainnya melakukan sesuatu. Industri versus inferioritas merupakan tugas dari perkembangan anak usia sekolah yang sejalan dengan pemaparan diatas (Diyantini, N. K., Yanti, N. L. P. E., \& Lismawati, 2015; Kozier, Erb, Berman, 2011; Potter, P.A., \& Perry, 2010). Anak usia sekolah dalam tahap ini, menyukai hal-hal baru yang mereka peroleh dengan bermain dan memuaskan rasa ingin tahunya melalui teknologi gadget. Gadget adalah perangkat teknis yang dapat dihubungkan ke berbagai aplikasi yang dimilikinya melalui internet (Garini, 2013).

Data survei (Asosiasi Penyelenggara Jasa Internet Indonesia, 2018) menemukan jenis aplikasi yang sering digunakan pada anak usia sekolah adalah youtube 98\%, dan game online 50\%. Bagi anak usia sekolah yang menggunakan gadget, pengawasan khusus oleh orang tua diperlukan agar anak tidak terpengaruh ketergantungan gadget, karena orang tua harus dapat membatasi anak bermain gadget dan tidak membiarkan anak mengabaikan tanggung jawabnya, seperti mandi, makan, belajar dan bermain dengan teman untuk bersosialisasi dengan baik (Sujianti, 2018)

Penelitian yang dilakukan oleh (Çağan et al., 2014), menyatakan bahwa ketergantungan dalam menggunakan gadget dapat memberikan dampak negatif pada kemampuan secara akademik. Hal ini sesuai dengan penelitian yang dilakukan oleh (Bansal \& Mahajan, 2017) yang menemukan bahwa penggunaan gadget berkaitan dengan perkembangan psikologis anak. Anak-anak sebaiknya menggunakan gadget selama satu hingga tiga jam sehari. Jika anak menggunakan gadget lebih dari empat jam sehari, anak dapat menyebabkan gangguan.

Fenomena permasalahan diatas menunjukkan bahwa jumlah anak yang menggunakan gadget cukup tinggi dan mempengaruhi perilaku anak usia sekolah. Oleh karena itu, peneliti perlu untuk meneliti mengenai bagaimana "Gambaran ketergantungan gadget pada anak usia sekolah". Tujuan dari penelitian ini adalah untuk mengidentifikasi karakteristik responden seperti jenis kelamin, usia, anak 
ke, kelas, jenis aplikasi yang digunakan, waktu penggunaan gadget, dan kepemilikan gadget. Serta mengidentifikasi gambaran ketergantungan gadget pada anak usia sekolah.

\section{METODE}

Penelitian ini menggunakan penelitian kuantitatif dengan jenis penelitian deskriptif. Lokasi penelitian ini dilakukan di SD Negeri 83 Pekanbaru. Waktu penelitian ini dimulai dari bulan Februari sampai September 2020. Populasi dalam penelitian adalah siswa/i kelas IV dan V yang menggunakan gadget setiap hari dengan 153 siswa. Sampel yang digunakan dalam penelitian ini ada purposive sampling dengan 30 responden. Peneliti mengambil 30 responden berdasarkan besar minimal sampel dalam penelitian yang telah dijelaskan oleh (Sugiyono, 2014). Pengambilan sampel dalam penelitian ini berdasarkan situasi saat pandemi COVID-19 di Indonesia lagi meningkatnya, sehingga penelitian ini hanya mengambil minimal sampel saja. Kriteria inklusi dalam penelitian ini, yaitu: a. Anak usia 10-11 tahun; b. Anak yang menggunakan gadget setiap harinya; c. Anak yang bisa membaca dan menulis; $d$. Mendapatkan persetujuan menjadi responden dari orang tua anak.
Peneliti mengumpulkan data dengan menggunakan kuesioner Smartphone Addiction Scale-Short Version (SAS-SV) yang sudah dimodifikasi oleh peneliti sendiri. Kuesioner penelitian ini menggunakan skala likert. Jumlah pernyataan di setiap aspek terdiri dari 15 pernyataan yang masing-masing penyataan terdapat pernyataan positif dan negatif. Pada kuesioner Smartphone Addiction Scale-Short Version (SAS-SV) dalam versi bahasa Indonesia yang sudah dimodifikasi oleh peneliti sendiri tidak dilakukan uji validitas dan reliabilitas sehingga terdapat keterbatasan dalam penelitian ini. Ini berkaitan dengan meningkatnya kasus wabah pandemi COVID-19 di Indonesia, dikarenakan meningkatnya wabah pandemi ini menyebabkan kegiatan belajar mengajar dilakukan secara daring.

Alur pengumpulan data dalam penelitian ini adalah dimulai dari peneliti meminta izin kepada pihak sekolah dan wali kelas tempat peneliti melakukan penelitian. Setelah itu, peneliti menjelaskan maksud dan tujuan penelitian kepada wali murid responden untuk mengisi data pada lembar kuesioner dan menandatangani informed concent. Pengambilan data dilakukan berdasarkan prosedur pencegahan COVID 19 seperti memakai masker (Faceshield); melakukan social distancing; dan tidak berjabat tangan antara peneliti dan 
responden. Pada tahap akhir penelitian, peneliti melakukan pemeriksaan kelengkapan pengisian kuesioner dan meminta surat bahwasannya peneliti sudah melakukan penelitian di SD tersebut. Analisa data dalam penelitian ini yaitu analisa deskriptif yang digunakan untuk mengidentifikasi gambaran penggunaan gadget pada anak usia sekolah, karakteristik responden (jenis Kelamin, usia, anak ke, kelas, aplikasi yang sering digunakan, waktu penggunaan gadget dan kepemilikan gadget). Penelitian ini telah memenuhi uji etik yang diajukan pada Fakultas Keperawatan Universitas Riau dengan

No.

\section{HASIL DAN PEMBAHASAN}

Tabel 1.

Distribusi Frekuensi Karakteristik Responden $(\mathrm{n}=30)$

\begin{tabular}{lcc}
\hline \multirow{2}{*}{ Karakteristik Responden } & Frekuensi & Persentase \\
\cline { 2 - 3 } & $(\mathrm{n})$ & $(\%)$ \\
\hline Usia Anak & 10 & 33,3 \\
10 tahun & 20 & 66,7 \\
11 tahun & & \\
& 21 & 70,0 \\
Jenis Kelamin & 9 & 30,0 \\
$\quad$ Laki-laki & & \\
$\quad$ Perempuan & 11 & 36,7 \\
\hline Anak Ke & 9 & 30,0 \\
1 & 8 & 26,7 \\
2 & 2 & 6,7 \\
3 & & \\
4 & 9 & 30,0 \\
\hline Kelas & 21 & 70,0 \\
4 & 30 & 100 \\
\hline Total & & \\
\hline
\end{tabular}

Tabel 1 didapatkan data bahwa dari 30 responden yang diteliti, paling banyak responden berusia 11 tahun $(66,7 \%)$ dan berjenis kelamin laki-laki (70\%). Responden lebih banyak anak pertama $(36,7 \%)$ dan berada di kelas $5(70,0 \%)$. Hasil penelitian menunjukkan karakteristik responden pada penelitian ini paling banyak anak berusia 11 tahun $(66,7 \%)$.
Selama periode ini, anak mulai memperoleh pengetahuan dasar atau kemampuan kognitif untuk memahami dunia baru, bertanggung jawab atas perilaku mereka di lingkungan sekitarnya, merasa rendah diri, berinteraksi dengan teman sebaya dan mendapatkan pujian atau peningkatan untuk mencapai rasa pencapaian. Pemaparan tersebut sejalan 
dengan industri versus inferioritas yang merupakan tugas dari perkembangan anak usia sekolah (Diyantini, N. K., Yanti, N. L. P. E., \& Lismawati, 2015; Kozier, Erb, Berman, 2011; Potter, P.A., \& Perry, 2010)

Hasil penelitian berdasarkan jenis kelamin menunjukkan paling banyak laki-laki (70\%). Hasil penelitian ini sejalan dengan penelitian (Liang, L., Zhou, D., Yuan, C., Shao., \& Bian, 2016) menyatakan bahwa pria lebih mungkin menderita kecanduan internet daripada wanita. Pria menggunakan internet untuk hiburan dan mengurangi stres, sedangkan wanita cenderung menggunakan internet untuk mencari tugas dan informasi tertentu.

Hasil penelitian berdasarkan urutan anak menunjukkan paling banyak terjadi pada anak pertama $(36,7 \%)$. Anak pertama disebut juga dengan anak sulung. Orang tua menuntut anak pertamanya menjadi lebih mandiri, bertanggung jawab, dan pekerja keras. Seperti halnya pandangan orang tua tentang penggunaan gadget yang memiliki pengaruh baik dalam membantu tugas sekolah anak, tidak jarang orang tua memberikan fasilitas seperti gadget kepada anak untuk mencari ilmu dan informasi terkait pelajaran sekolah (Nalika, 2014).

Hasil penelitian berdasarkan kelas menunjukkan paling banyak terjadi di kelas 5 (70,0\%). Mayoritas anak kelas 5 dan 6 SD Negeri 83 Pekanbaru sudah diperbolehkan membawa gadget ke lingkungan sekolah. Gadget ini hanya digunakan setelah anak selesai belajar dan menghubungi orang tua untuk meminta jemputan. Penggunaan gadget pada anak sering disalahgunakan untuk menonton video di YouTube atau game untuk mengisi waktu sambil menunggu jemputan. 
Tabel 2

Distribusi Karakteristik Penggunaan Gadget $(\mathrm{n}=30)$

\begin{tabular}{ccc}
\hline Karakteristik Responden & Frekuensi & Persentase \\
\cline { 2 - 3 }$(\%)$ & $(\mathrm{n})$ & 83,3 \\
Aplikasi yang digunakan & 25 & 10,0 \\
Games & 3 & 6,7 \\
Sosial Media & 2 & \\
Youtube & & 26,7 \\
< 1 Jam & 8 & 36,7 \\
1-2 Jam & 11 & 10,0 \\
2-3 Jam & 3 & 26,7 \\
Z3 Jam & 8 & 30,0 \\
Waktu Penggunaan Gadget & & 63,3 \\
Sendiri & 9 & 6,7 \\
Orang tua & 19 & 100 \\
Saudara Kandung & 2 & \\
Total & 30 &
\end{tabular}

Tabel 2 dapat disimpulkan paling banyak responden yang menggunakan gadget dengan tujuan mengakses aplikasi games yakni $(83,3 \%)$ dengan waktu penggunaan gadget adalah 1-2 Jam (36,7\%) dan kepemilikan gadget masih milik orang tua sebanyak $(63,3 \%)$.

Hasil penelitian menunjukkan aplikasi yang sering digunakan adalah games $(83,3 \%)$. Penelitian ini sejalan dengan penelitian (Karuniasari, 2017) yang menyatakan bahwa anak usia sekolah menggunakan gadget untuk bermain game karena alasan yang menyenangkan dan membuat ketagihan, berteman dan menampilkan gambar yang menarik. Intensitas waktu permainan rata-rata \pm 24 jam / minggu.

Hasil penelitian menunjukkan waktu ratarata penggunaan gadget dalam sehari yakni selama 1-2 Jam sebanyak 11 orang $(36,7 \%)$. Penelitian ini sejalan dengan pernyataan American and Canadian Association of Pediatricians (Permata, 2015), yang menyatakan "Anak-anak antara usia 6-18 tahun hanya dapat menggunakan gadget selama dua jam sehari." Hal ini serupa dengan di Amerika Serikat Pediatrician Cris Rowan di Huffington Post, bahwa penggunaan gadget oleh anak di bawah usia 12 tahun itu perlu (Sumarni, 2016)

Hasil penelitian menunjukkan paling banyak responden menggunakan gadget milik orang tua $(63,3 \%)$. Hal tersebut juga diungkapkan oleh (Rozalia, 2017), bahwa orang tua bermain dengan anak karena mereka percaya bahwa gadget memiliki efek positif bagi anak, yaitu belajar, meningkatkan kemampuan motorik dan 
aktivitas bermain. Aplikasi edukasi pada gadget bahkan game edukasi dapat meningkatkan tumbuh kembang anak usia sekolah.

Tabel 3

Distribusi Frekuensi Responden Ketergantungan Gadget $(\mathrm{n}=30)$

\begin{tabular}{|c|c|c|c|c|c|c|}
\hline \multirow{3}{*}{ Aspek Kecanduan Gadget } & \multicolumn{4}{|c|}{ Kategori kecanduan gadget } & \multirow{2}{*}{\multicolumn{2}{|c|}{ Total }} \\
\hline & \multicolumn{2}{|c|}{ Tinggi } & \multicolumn{2}{|c|}{ Rendah } & & \\
\hline & $\mathrm{N}$ & $\%$ & $\mathrm{~N}$ & $\%$ & $\mathrm{~N}$ & $\%$ \\
\hline Daily $\quad$ Life $\quad$ Disturbance & & & & & & \\
\hline $\begin{array}{l}\text { (Gangguan Kehidupan Sehari- } \\
\text { hari) }\end{array}$ & 13 & 43,3 & 17 & 56,7 & 30 & 100,0 \\
\hline $\begin{array}{l}\text { Positive Anticipation (Antisipasi } \\
\text { Positif) }\end{array}$ & 17 & 56,7 & 13 & 43,3 & 30 & 100,0 \\
\hline $\begin{array}{l}\text { Withdrawal (Kecenderungan Diri } \\
\text { dari Kehidupan Sosial) }\end{array}$ & 12 & 40,0 & 18 & 60,0 & 30 & 100,0 \\
\hline $\begin{array}{l}\text { Cyberspace Oriented Relationship } \\
\text { (Orientasi Terhadap Hubungan } \\
\text { Dunia Maya) }\end{array}$ & 12 & 40,0 & 18 & 60,0 & 30 & 100,0 \\
\hline $\begin{array}{l}\text { Over Use (Penggunaan yang } \\
\text { Berlebihan) }\end{array}$ & 15 & 50,0 & 15 & 50,0 & 30 & 100,0 \\
\hline $\begin{array}{lll}\text { Tolerance } & \text { (Kurangnya } & \text { Sikap } \\
\text { Toleransi } & & \end{array}$ & 17 & 56,7 & 13 & 43,3 & 30 & 100,0 \\
\hline
\end{tabular}

Berdasarkan tabel 3, ketergantungan gadget yang dialami responden terjadi pada antisipasi positif dan kurangnya sikap toleransi $(56,7 \%)$ dengan tingkat ketergantungan yang tinggi sedangkan untuk tingkat ketergantungan rendah yang mengalami kecenderungan diri dari kehidupan sosial dan orientasi terhadap hubungan dunia maya sebanyak $(60,0 \%)$.

Hasil penelitian menunjukkan bahwa paling banyak anak berada pada kategori rendah yang memiliki gangguan kehidupan sehari-hari $(56,7 \%)$. Hal ini berarti gadget tidak mengganggu kehidupan sehari-hari anak usia sekolah. Hasil penelitian ini sejalan dengan penelitian (Sujianti, 2018) yang menyatakan bahwa menggunakan gadget tidak hanya akan membawa efek negatif, tetapi juga banyak efek positif akibat penggunaan gadget. Gadget juga dapat digunakan sebagai sarana pembelajaran untuk meningkatkan kemampuan berbahasa, karena gadget memiliki banyak fungsi yang dapat mengurangi tingkat stres, dll. Namun, anak yang menggunakan gadget perlu pengawasan khusus oleh orang tuanya agar anaknya tidak terkena kecanduan gadget, karena orang tua harus bisa membatasi anaknya bermain gadget dan tidak membiarkan anaknya melalaikan tugasnya, seperti mandi, makan, dan belajar. 
Hasil penelitian ini menunjukkan bahwa tinggi perilaku antisipasi positif $(56,7 \%)$. Pernyataan berikut juga sesuai dengan pernyataan (Yuwanto, 2010) yang memaparkan secara psikologis, ketika seseorang tidak menggunakan atau membawa smartphone, dia merasa tidak nyaman atau cemas. Ini akan membuat anak merasa lebih berarti saat menggunakan gadget. Kecanduan smartphone dapat menimbulkan terjadinya penurunan hubungan langsung dengan orang lain. Kecanduan smartphone akan membuat waktu untuk melakukan hal-hal yang berguna terkuras dan mengurangi efisiensi kerja yang akan mengusik pembelajaran dan aktivitas anak dalam kehidupannya.

Hasil penelitian menunjukkan bahwa tidak terjadi penarikan diri pada anak $(60,0 \%)$. Hasil tersebut tidak serupa dengan (Kwon et al., 2013) yang menunjukkan bahwa penderita kecanduan smartphone akan memperlihatkan rasa tidak sabar, cemas dan mudah tersinggung saat menggunakan smartphone.

Hasil penelitian menunjukkan bahwa paling banyak anak tidak mengalami orientasi terhadap hubungan dunia maya sebanyak $(60,0 \%)$. Hal ini tidak sejalan dengan pernyataan (Kuss \& Griffiths, 2011) yang menyatakan penggunaan ponsel cerdas dalam waktu lama akan menimbulkan masalah psikis atau perilaku. Hal ini mengakibatkan terganggunya kegiatan sekolah atau keluarga, berkurangnya hubungan sosial, terjadinya pengabaian pada diri pribadi, gangguan mental, perubahan emosi, serta dapat menimbulkan putus hubungan dengan orang lain.

Hasil penelitian menunjukkan bahwa jumlah penggunaan gadget yang berlebihan sama antara kategori tinggi maupun kategori rendah sebanyak (50,0\%). Sehingga dapat disimpulkan bahwa minim terjadi pada anak yang menggunakan gadget secara berlebihan ataupun sebaliknya. Hasil penelitian ini sejalan dengan (Kwon et al., 2013) yang mengemukakan bahwa penggunaan berlebihan dapat menyebabkan pengguna cenderung mencari bantuan melalui smartphone mereka, dan merasakan desakan untuk terus menggunakan smartphone mereka segera setelah mereka memutuskan untuk berhenti menggunakan smartphone. Ini dapat disimpulkan bahwa penderita kecanduan smartphone akan menunjukkan penggunaan smartphone yang berlebihan.

Hasil penelitian menunjukkan bahwa tingginya sikap toleransi, sebanyak $(56,7 \%)$. Hal ini dapat disimpulkan bahwa kecanduan gadget mempengaruhi toleransi anak terhadap orang lain dan dirinya 
sendiri. Terlihat dari penggunaan ponsel pintar bahwa toleransi waktu ini melebihi waktu yang diperlukan. Hal ini sejalan dengan penelitian (Haug et al., 2015) mengungkapkan bahwa gejala kecanduan smartphone akan terlihat dengan adanya penggunaan yang lebih lama dari biasanya. Namun jumlah waktu yang dihabiskan menggunakan smartphone dianggap suatu hal yang normal (Hussain et al., 2017) Selain itu anggapan tidak adanya anggapan orang sekitar terhadap penggunaan smartphone yang lama. Ini yang menyebabkan tidak adanya perasaan bahwa dirinya menggunakan smartphone yang berlebihan.

Penelitian ini masih memiliki beberapa keterbatasan berkaitan dengan wabah pandemi COVID-19 di Indonesia, hal ini menyebabkan peneliti tidak dapat menguji validitas dan reliabilitas dari kuesioner penelitian ini. Selain itu, pengukuran dalam penelitian ini hanya menggunakan kuesioner sehingga peneliti merasa kesulitan dalam melakukan observasi untuk memahami aktivitas ketergantungan penggunaan gadget pada anak usia sekolah.

\section{SIMPULAN}

Hasil penelitian terhadap 30 anak yang menggunakan gadget setiap hari menunjukkan bahwa ketergantungan terhadap penggunaan gadget termasuk dalam kategori tinggi (53,3\%). Hasil penelitian ini dapat disimpulkan bahwa paling banyak anak yang mengalami ketergantungan penggunaan gadget sehingga anak mengalami banyak sekali dampak negatif yang ditimbulkan dari gadget. Penelitian ini merekomendasikan kepada masyarakat khususnya keluarga untuk dapat mengawasi anaknya dalam penggunaan gadget dan dapat mencegah terjadinya kecanduan pada anak usia sekolah.

\section{UCAPAN TERIMA KASIH}

Terima kasih kepada semua pihak yang telah berperan dalam kelancaran dan kesuksesan untuk penelitian ini.

\section{DAFTAR RUJUKAN}

Asosiasi Penyelenggara Jasa Internet Indonesia. (2018). Infografis penetrasi dan perilaku pengguna internet indonesia survey 2018. APJII. http://www.apjii.or.id

Bansal, S., \& Mahajan, R. C. (2017). Impact of mobile use amongst children in rural area of Marathwada region of Maharashtra, India. International Journal of Contemporary Pediatrics, 5(1), 50. https://doi.org/10.18203/23493291.ijcp20175138 
Çağan, Ö., Ünsal, A., \& Çelik, N. (2014). Evaluation of College Students' the Level of Addiction to Cellular Phone and Investigation on the Relationsship between the Addiction and the Level of Depression. Procedia - Social and Behavioral Sciences, 114, 831-839. https://doi.org/10.1016/j.sbspro.2013. 12.793

Diyantini, N. K., Yanti, N. L. P. E., \& Lismawati, S. M. (2015). Hubungan karakteristik dan kepribadian anak dengan kejadian bullying pada siswa kelas v di SD " $x$ " di Kabupaten Badung. (Community of Publishing in Nursing, 3 .

Garini. (2013). Gadget positif \& negatif. $\mathrm{http}: / /$ mairaindonesia.com

Haug, S., Paz Castro, R., Kwon, M., Filler, A., Kowatsch, T., \& Schaub, M. P. (2015). Smartphone use and smartphone addiction among young people in Switzerland. Journal of Behavioral Addictions, 4(4), 299307.

https://doi.org/10.1556/2006.4.2015.0 37

Hussain, Z., Griffiths, M. D., \& Sheffield, D. (2017). An investigation into problematic smartphone use: The role of narcissism, anxiety, and personality factors. Journal of Behavioral Addictions, 6(3), 378386.

https://doi.org/10.1556/2006.6.2017.0 52

Karuniasari, Z. (2017). Peran kontrol sosial dalam menghadapi kecanduan game online pada remaja. Universitas Muhammadiyah Surakarta.
Kesehatan, K. (2011). Gizi lebih merupakan ancaman masa depan anak. Kementrian Kesehatan. http://depkes.go.id

Kozier, Erb, Berman, \& S. (2011). Buku ajar fundamental keperawatan: Konsep, proses \& praktik (7 ed., vol 1). (7th ed.). EGC.

Kuss, D. J., \& Griffiths, M. D. (2011). Online social networking and addiction-A review of the psychological literature. International Journal of Environmental Research and Public Health, 8(9), 3528-3552. https://doi.org/10.3390/ijerph8093528

Kwon, M., Lee, J. Y., Won, W. Y., Park, J. W., Min, J. A., Hahn, C., Gu, X., Choi, J. H., \& Kim, D. J. (2013). Development and Validation of a Smartphone Addiction Scale (SAS). PLoS ONE, 8(2). https://doi.org/10.1371/journal.pone.0 056936

Latifa, U. (2017). Aspek Perkembangan pada Anak Sekolah Dasar: Masalah dan Perkembangannya. Journal of Multidisciplinary Studies, 1(2), 185196.

Liang, L., Zhou, D., Yuan, C., Shao., \& Bian, Y. (2016). Gender differences in the relationship between internet addiction and depression: a crosslagged study in Chinese adolescents. Computers in Human Behavior, 63, 463-470. https://doi.org/10.1016/j.chb.2016.04. 043 
Nalika, U. (2014). Mobile Device Usage Among Young Kids: A Southeast Asia Study. Asianparent Insights Mobile, November, 1-61. https://s3ap-southeast-1.amazonaws.com/tapsg-

media/theAsianparent+Insights+Devi ce+Usage+A+Southeast+Asia+Study + November+2014.pdf

Permata, D. cahya. (2015). Pemanfaatan ponsel cerdas sebagai media belajar bagi orangtua dalam mendukung stimulasi perkembangan anak usia dini (studi pada orangtua di kelurahan ledeng kecamatan cidadap kota bandung). Jurnal Universitas Pendidikan Indonesia.

Potter, P.A., \& Perry, A. G. (2010). Fundamental keperawatan (7th ed.). Salemba Medika.

Rozalia, M. F. (2017). Hubungan intensitas pemanfaatan Gawaidengan prestasi belajar siswa kelas V sekolah dasar. Jurnal Pemikiran Dan Pengembangan Sd, 5, 722-731.
Sugiyono. (2014). Metode penelitian kuantitatif, kualitatif dan $R \& D$. Alfabeta.

Sujianti, S. (2018). Hubungan Lama Dan Frekuensi Penggunaan Gadget Dengan Perkembangan Sosial Anak Pra Sekolah Di Tk Islam Al Irsyad 01 Cilacap. Jurnal Kebidanan, 8(1), 54. https://doi.org/10.31983/jkb.v8i1.373 5

Sumarni, T. (2016). Pengaruh gadget dalam pendidikan. Slamet Hariyanto. https://suaraguru.wordpress.com

Yuwanto, L. (2010). Causes of Mobile Phone Addiction. Anima Indonesian Psychological Journal, 25(3), 225229. 